\title{
Fillers for the improvement in acne scars
}

This article was published in the following Dove Press journal:

Clinical, Cosmetic and Investigational Dermatology

29 September 2015

Number of times this article has been viewed

\author{
Uwe Wollina' \\ Alberto Goldman² \\ 'Department of Dermatology and \\ Allergology, Academic Teaching \\ Hospital, Dresden-Friedrichstadt, \\ Dresden, Germany; ${ }^{2}$ Clinica Goldman, \\ Porto Alegre, Rio Grande do Sul, \\ Brazil
}

\begin{abstract}
Acne is a common inflammatory disease. Scarring is an unwanted end point of acne. Both atrophic and hypertrophic scar types occur. Soft-tissue augmentation aims to improve atrophic scars. In this review, we will focus on the use of dermal fillers for acne scar improvement. Therefore, various filler types are characterized, and available data on their use in acne scar improvement are analyzed.
\end{abstract}

Keywords: acne, scars, dermal fillers, injection, extracellular matrix

\section{Introduction}

Acne is a common disease. Its prevalence is $\sim 80 \% .{ }^{1}$ Almost $10 \%$ of the World population are affected. ${ }^{2}$ Onset of acne in most patients is during puberty, but acne among adults, especially females, is not rare. ${ }^{3,4}$ Scarring is an unwanted end point of the diseases and not restricted to severe disease subsets. ${ }^{1,5}$

For clinical trials and scoring of severity of acne scars, several algorithms have been developed. The most popular is the "Quantitative Global Scarring Grading System for Post-acne Scarring"6 of which a Brazilian Portuguese version exists. ${ }^{7}$ Skin picking syndrome is a differential diagnosis of acne scars with an overlap in acne excoriee. ${ }^{8}$ The Quantitative Global Scarring Grading System for Postacne Scarrin" differentiates four grades: I with macular flat marks of different color; II with mild atrophic or hypertrophic scars; III with moderate atrophic or hypertrophic scars; and IV with severe atrophic or hypertrophic scars. ${ }^{6}$

\section{Acne scars}

The mechanism of scarring in acne is complex. The basic inflammatory process of acne becomes more pronounced in patients with acne scarring. ${ }^{9}$ This leads to an aberrant remodeling of the extracellular matrix (ECM) in pilosebaceous units of skin. Propionibacterium acnes and other gram-positive bacteria are capable to increase the formation of matrix metalloproteinase- 2 in sebocytes and skin fibroblasts, which may contribute to a distorted degradation of ECM. ${ }^{10}$ Furthermore, peptidoglycans of gram-positive bacteria enhance the production of prostaglandin E2. ${ }^{11}$

Color scarring in skin is more common and often associated with postinflammatory hyperpigmentation. This can be due to genetics, pigmentation, and differences in skin care. $^{12}$

There are different clinical types of acne scars, ie, atrophic and hypertrophic scars. Atrophic scars can be further differentiated into deep and narrow icepick scars, larger roll- 
ing scars, and depressed boxcar scars (Figure 1). Hypertrophic scars and acne keloids represent the hypertrophic variants. ${ }^{13}$

Acne scar management needs an effective control of inflammation, which could prevent scarring. The treatment of scars includes different approaches, namely, camouflage, peelings, microneedling, subcision, and laser therapy for atrophic scars. Hypertrophic scars may be treated by cryotherapy, corticosteroids injections, laser, and surgery. ${ }^{13,14}$ All procedures may improve scars but cannot establish a scar-free skin. ${ }^{15}$

In this review, we will focus on the correction of ECM aberrations by the use of dermal fillers with the focus on atropic acne scars.

\section{Dermal fillers}

Dermal fillers can be classified as temporary, semipermanent, and permanent (Table 1). Although the first two classes are biodegradable with a broad range of half-lives, permanent fillers are not biodegradable. ${ }^{16}$ Fillers induce a characteristic ECM response that allows a histopathological identification of various filler types. ${ }^{17}$

Tolerability and safety of dermal filler implantation are dependent upon filler qualities, skills and knowledge of the medical doctor, and patient characteristics. ${ }^{18-20}$

The injection of dermal fillers to improve acne scars is based on soft-tissue augmentation. Hyaluronic acid fillers (HAFs) stimulate collagen production. A stronger stimulation of collagen production is seen with semipermanent or biostimulatory fillers, ie, poly-L-lactic acid (PLL) and calcium hydroxylapatite (CaHA), and permanent fillers. ${ }^{17}$

Basic knowledge of filler qualities, injection techniques, and anatomy is indispensable. Fillers should not be used in children and youngsters, in pregnant or nursing women, in patients with immune disorders, allergies against filler materials, and infections. Filler implantation warrants hygienic standards and should not be used in case of dental root procedures and skin barrier injuries to minimize the potential risk of infection. Knowledge of possible unwanted adverse effects, their prevention, and management are prerequisites. ${ }^{21}$

Several injection techniques are used, such as serial punctures, linear threading, fanning and cross-hatching, deep bolus, or superficial microdroplet injections. ${ }^{21}$ Cooling of the skin before and after injections reduces pain and bruising. ${ }^{22}$

\section{Dermal fillers for acne scars - clinical evidence Silicone microdroplet injections}

Medical-grade silicon has been used for a long time as a type of permanent filler in soft-tissue augmentation (Table 2).
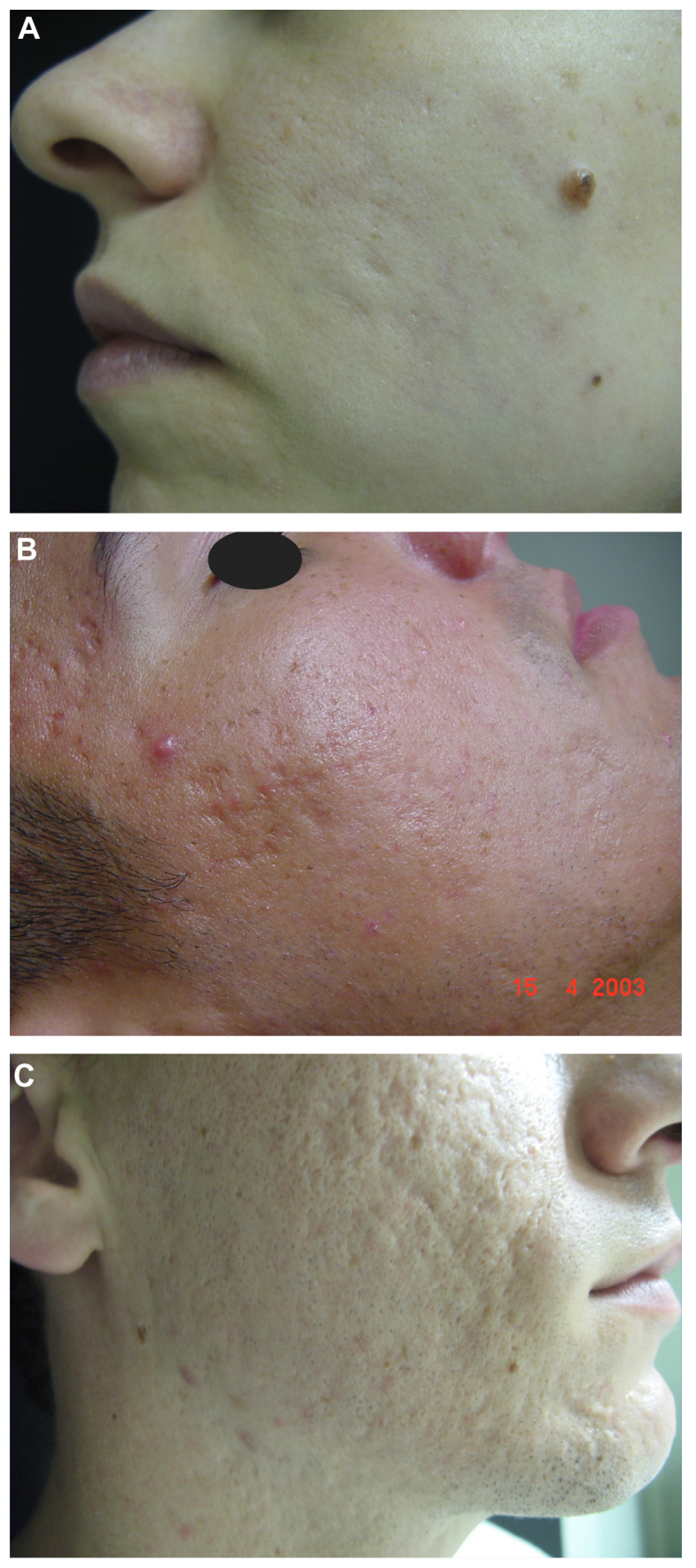

Figure I Acne scars.

Notes: (A) Rolling acne scars with an undulating appearance; (B) acne boxcar scars with a round or oval shape resembling varicella scars; and (C) icepick scars are sharply demarcated, narrow, and deep.

Proponents of silicon argue that the product is stable, has some antimicrobial activity, and is relatively cheap. Repeated microdroplet silicone injections are recommended with longlasting effects..$^{23,24}$

A 1,000 centistoke-injectable silicone emulsified with hyaluronic acid (HA; Silikone ${ }^{\circledR}$ Alcon, Fort Worth, TX, USA.) was used in 95 patients for tissue augmentation with only 
Table I Dermal filler classification

\begin{tabular}{|c|c|c|}
\hline Filler class & $\begin{array}{l}\text { Average clinical } \\
\text { efficacy }\end{array}$ & Examples \\
\hline Temporary & $3-18$ months & $\begin{array}{l}\text { Hyaluronic acid } \\
\text { and collagen }\end{array}$ \\
\hline Semipermanent & Up to 24 months & $\begin{array}{l}\text { Poly-L-lactic acid and } \\
\text { calcium hydroxylapatite }\end{array}$ \\
\hline Permanent & $\begin{array}{l}\text { Many years if not } \\
\text { lifelong }\end{array}$ & $\begin{array}{l}\text { Silicon, polyacrylamide, } \\
\text { polymethacrylate, and } \\
\text { hydroxyethylmethacrylate }\end{array}$ \\
\hline
\end{tabular}

minor temporary adverse effects. ${ }^{24}$ The American Society for Dermatologic Surgery listed acne scars as a possible indication for liquid silicone injections. ${ }^{22}$

The 1,000 centistoke silicone oil is Food and Drug Administration (FDA) approved "for use as a prolonged retinal tamponade in selected cases of complicated retinal detachments where other interventions are not appropriate for patients. ${ }^{25}$ None of the silicone products are approved as soft-tissue fillers. Cosmetic filler injections have been associated with severe adverse effects, such as infection, calcifications, pneumonitis, pulmonary embolism, renal failure, and death. ${ }^{26,27}$ Although many of these severe complications were noted by unlicensed practitioners or lay people, the use of silicone is off-label and is not recommended by us. ${ }^{28}$ Migration of silicone is another problem, leading to unwanted adverse effects. ${ }^{29}$

\section{Polymethylmethacrylate microspheres}

Polymethylmethacrylate (PMMA) is an inert, synthetic permanent filler material that induces fibrous capsule formation in animals. ${ }^{30}$ For cosmetic use, 20\% PMMA microspheres are

Table 2 Clinical trials with dermal fillers for atrophic acne scars

\begin{tabular}{|c|c|c|c|c|}
\hline Filler material & Number of patients & Remarks & Outcome & Reference \\
\hline Silicone & 5 & $\begin{array}{l}\text { Retrospective case series; repeated } \\
\text { microdroplet injections }\end{array}$ & Stable for $10-20$ years & 22 \\
\hline $\begin{array}{l}\text { Silicone with HA } \\
\left(\text { Silikone }^{\circledR}\right)\end{array}$ & 95 (incl acne scars) & $\begin{array}{l}\text { Retrospective analysis; microdroplet } \\
\text { injections }\end{array}$ & $\begin{array}{l}\text { Stable for at least } 2 \text { years } \\
\text { (follow-up) }\end{array}$ & 23 \\
\hline PMMA (Artecoll $\left.{ }^{\circledR}\right)$ & 72 (incl acne scars) & $\begin{array}{l}\text { Retrospective analysis; some } \\
\text { patients with repeated injections }\end{array}$ & $\begin{array}{l}85 \% \text { of patients satisfied } \\
\text { four patients with nodule formation }\end{array}$ & 30 \\
\hline PMMA (Artefill ${ }^{\circledR}$ ) & 14 & $\begin{array}{l}\text { Retrospective analysis combined } \\
\text { with subcision }\end{array}$ & $\begin{array}{l}96 \% \text { of scare moderate improved } \\
\text { after } 8 \text { months }\end{array}$ & 32 \\
\hline PMMA (Artefill ${ }^{\circledR}$ vs saline) & $\begin{array}{l}\text { I } 47 \text { (with } \geq 4 \\
\text { atrophic rolling scars) }\end{array}$ & $\begin{array}{l}\text { Double-blind, randomized, } \\
\text { multicenter, and controlled trial; } \\
\text { two treatments per scar }\end{array}$ & $\begin{array}{l}\text { Scar improvement in } 64 \% \text { (PMMA) vs } \\
33 \% \text { (saline) after } 6 \text { months }\end{array}$ & 33 \\
\hline PMMA (Bellafill $\left.{ }^{\circledR}\right)$ & 133 & $\begin{array}{l}\text { Double-blind, randomized, } \\
\text { multicenter, and controlled trial }\end{array}$ & $\begin{array}{l}\text { Improvement in }>50 \% \text { of cheek } \\
\text { scars after } 6 \text { months } 64 \% \text { (PMMA) vs } \\
33 \% \text { (saline), stable after } \\
12 \text { months (follow-up without } \\
\text { treatment) }\end{array}$ & 34 \\
\hline $\begin{array}{l}\text { Polyacrylamide } \\
\left(\text { Aquamide }^{\circledR}\right)\end{array}$ & 228 (incl acne scars) & $\begin{array}{l}\text { Retrospective study with I2-month } \\
\text { follow-up }\end{array}$ & After 12 months, $93 \%$ satisfaction & \\
\hline PLL (Sculptra $\left.{ }^{\circledR}\right)$ & $\begin{array}{l}20 \text { (acne and } \\
\text { postvaricella scars) }\end{array}$ & $\begin{array}{l}\text { Prospective open trial with up to } \\
\text { seven treatments }\end{array}$ & $\begin{array}{l}\text { Significant reduction in scar size } \\
\text { and severity }\end{array}$ & 38 \\
\hline PLL $\left(\right.$ Newfill $\left.{ }^{\circledR}\right)$ & 22 (rolling acne scars) & $\begin{array}{l}\text { Open phase II trial, three to } \\
\text { four treatments }\end{array}$ & Improvement in $68.2 \%$ of patients & 40 \\
\hline CaHA $\left(\right.$ Radiesse $\left.^{\circledR}\right)$ & 10 & Open trial & $\begin{array}{l}\text { Improvement in boxscars not } \\
\text { icepick scars }\end{array}$ & 42 \\
\hline CaHA (Radiesse ${ }^{\circledR}$ ) & 42 & $\begin{array}{l}\text { Open trial after subcision I week } \\
\text { before }\end{array}$ & $\begin{array}{l}\text { After } 12 \text { months, } 48 \% \text { of patients } \\
\text { had a } 50 \% \text { improvement and } 22 \% \\
\text { had a } 75 \% \text { improvement }\end{array}$ & 43 \\
\hline Collagen (Zyplast ${ }^{\circledR}$ ) & I 88 (incl acne scars) & Retrospective analysis & $\begin{array}{l}83 \% \text { patient satisfaction, } 3 \% \text { allergic } \\
\text { reactions to the filler material }\end{array}$ & 44 \\
\hline Collagen $\left(\right.$ Zyderm I ${ }^{\circledR}$ ) & 18 & Open trial with $\geq 3$ treatments & $\begin{array}{l}\text { Improvement in "soft" scars but } \\
\text { failure with fibrotic and icepick scars }\end{array}$ & 45 \\
\hline Collagen $\left(\right.$ Zyderm ${ }^{\circledR}$ ) & 20 & $\begin{array}{l}\text { Split-face study with collagen vs } \\
\text { subcision }\end{array}$ & $\begin{array}{l}\text { At } 3 \text { months and } 6 \text { months, patients } \\
\text { rated subcision higher, no difference } \\
\text { found by blinded evaluators }\end{array}$ & 46 \\
\hline HAF (Esthelis ${ }^{\circledR}$ ) & 12 & Open trial & $\begin{array}{l}\text { Patients score } 42 \% \text { good and } 58 \% \\
\text { excellent after I month }\end{array}$ & 51 \\
\hline HAF (Restylane ${ }^{\circledR}$ ) & 12 & Open trial, HAF after fractional laser & Improvement in $100 \%$ of patients & 52 \\
\hline
\end{tabular}

Abbreviations: HA, hyaluronic acid; incl, including; PMMA, polymethylmethacrylate; PLL, poly-L-lactic acid; CaHA, calcium hydroxylapatite; HAF, hyaluronic acid filler. 
suspended in an aqueous solution of bovine collagen and lidocaine (Artecoll ${ }^{\circledR}$ and Artefill ${ }^{\circledR}$ Canderm Pharma, Saint Lorent, QC, Canada). Artecoll ${ }^{\circledR}$ and Artefill ${ }^{\circledR}$ have the same composition, although the microspheres are somewhat smaller in Artefill ${ }^{\circledR}$. In the hands of experienced users, patient satisfaction with PMMAtissue augmentation is high and the effect is long lasting. ${ }^{31,32}$ Most patients experience a moderate improvement. ${ }^{33,34}$ However, adverse effects can also be long lasting due and very nasty to the permanent nature of this filler material. ${ }^{31}$

Nevertheless, in 2014, Bellafill ${ }^{\circledR}$ (previously named Artefill $^{\circledR}$ ) has got FDA approval "for moderate-to-severe, atrophic, distensible facial acne scars on the cheek in patients over 21 years of age. ${ }^{25}$ This makes Bellafill ${ }^{\circledR}$ the first FDA-approved medical device for correction of acne scars. The scientific background is based on the clinical trial SUN-11-001, a prospective, randomized, multicenter, and evaluator-blind study for correction facial acne scars on the cheek. Patients were randomized 2:1 for Bellafill ${ }^{\circledR}(n=87)$ or sterile saline injection. ${ }^{46}$ Adult patients with Fitzpatrick skin types-I-VI were included. Data were analyzed at 6 months and after 12-month follow-up. Patients in the control group received on average higher injection volumes in primary treatment session and touch-up. Treatment-related adverse effects were noted in 14 patients with Bellafill ${ }^{\circledR}$ and in none of the control group. Bruising, injection pain, erythema, and lumpiness were observed but mild-to-moderate in 13 of the 14 patients. One case suffered from severe bruising. ${ }^{35}$

\section{Polyacrylamide}

Polyacrylamide is produced by polymerization of acrylamide monomers and by cross-linking with $N, N^{\prime}$-methylenbisacrylamide. Aquamid $^{\circledR}$ is a nonabsorbable hydrogel that consists of $2.5 \%$ cross-linked polyacrylamide and $97.5 \%$ water. Although it has been extensively used for soft-tissue augmentation, no controlled trial of Aquamid ${ }^{\circledR}$ for acne scars has been identified. ${ }^{36}$ Two uncontrolled trials not exclusive for patients with acne scars reported high satisfaction rates and up to $5 \%$ adverse effects, such as swelling, lumpiness, and abscess formation..$^{37,38}$

\section{Poly-L-lactic acid}

PLL is a biodegradable, semipermanent, and biostimulatory filler stimulating fibrous tissue formation. The commercially available product (Sculptra ${ }^{\circledR}$ and Newfill ${ }^{\circledR}$ Dermik Laboratories, Bridgewater, NJ, USA) consists of PLL microparticles, sodium carboxy-methylcellulose, and mannitol. Soft-tissue augmentation may last for up to 2 years. ${ }^{22}$

Two open trials and case reports recorded a significant improvement in atrophic acne scars, which may last for up to
4 years. ${ }^{39-41}$ Nodules developed in a single patient. ${ }^{41}$ Nodule formation with PLL can be due to too superficial injection and/or inappropriate dilution. A higher dilution than used for correction of human deficiency virus-associated midfacial lipoatrophy is recommended.

\section{Calcium hydroxylapatite}

CaHA is a synthetic, biodegradable, semipermanent, and biostimulatory filler. The commercially available product (Radiesse ${ }^{\circledR}$ Merz Pharma, Frankfurt, Germany) contains $30 \%$ CaHA microparticles suspended in a carboxy-methylcellulose gel. CaHA stimulates collage production. Softtissue augmentation lasts for up to 18 months. ${ }^{42}$ Open trials reported improvement in boxcar scars but failure in icepick scars, suggesting for a combination of $\mathrm{CaHA}$ with subcision for better outcome. ${ }^{43,44}$

\section{Collagen}

Collagen fillers are temporary fillers of either bovine, porcine, or recombinant human origin. The predominant collagen is collagen I as in human dermis. For bovine collagen fillers $\left(Z_{\text {Zyderm }}^{\circledR}\right.$ I and II, INAME Aesthetics, Santa Barbara, CA, USA), two intradermal skin tests 2-4 weeks apart are recommended due to its allergenic potential. The skin test is not necessary for porcine collagen (Evolence ${ }^{\circledR}$ ColBar LifeScience, Herzliya, Israel) or recombinant human collagen (Cosmoderm ${ }^{\circledR}$ and Cosmoplast ${ }^{\circledR}$ Allergan, Dublin, Ireland). Collagen fillers should not be used in patients with autoimmune diseases or collagen hypersensitivity. Soft-tissue augmentation usually persists up to 6 months..$^{45-47}$ The use of collagen fillers for atrophic acne scars was recommended by the American Society for Dermatologic Surgery. ${ }^{22}$

A case report suggested that in some patients, the effect may persist for at least 12 months. $^{48}$

\section{Hyaluronic acid filler}

HA is a glycosaminoglycan polysaccharide and a physiologic component of ECM. Natural HA has the disadvantage of a short half-life of 12 hours only. Therefore, various technologies for cross-linking have been developed to stabilize HAF. Linking agents include 1,4-butanediol diglycidyl ether, divinyl sulfone (DVS), and 2,7,8-diepoxyoctane. Modern HAFs are produced by bacterial fermentation. HAF can be divided into mono- (Esthelis ${ }^{\circledR}$ Anthies, Geneva, Switzerland/ Belotero $^{\circledR}$ Merz Pharma, Frankfurt, Germany, Juvederm ${ }^{\circledR}$ Allergan, Dublin, Ireland, etc) or biphasic (Perlane ${ }^{\circledR}$, Restylane ${ }^{\circledR}$ Galderma, Sophia Anitpolis, France), whereas biphasic fillers contain HA particles suspended in HA gel. ${ }^{18}$ 
HAFs differ in their cross-linking technology, percentage of cross-linking, the amount of HA and bound water, viscosity, hardness, cohesivity, HA concentration, gel-to-fluid ratio, degree of HA modification, swelling, modulus, particle size (for biphasic HAF), ease of injection, and approved indications. ${ }^{49}$ This allows tailored treatment of various conditions. Injection of HAF stimulates collagen production by fibroblasts contributing to soft-tissue augmentation. ${ }^{50}$

Open trials suggest a high treatment satisfaction of patients. Most common adverse effects were mild transitory erythema and mild-to-moderate pain during injection. ${ }^{51,52}$ Pneumatic injection of HA was used in two patients to improve acne scars by one grade. ${ }^{53} \mathrm{HAF}$ offers the opportunity of a rapid correction of nodules, etc, by the use of hyaluronidase injection. ${ }^{54}$

\section{Comparison with other treatments for atrophic acne scars}

All treatments for acne scar aim not to cure but to make the scars less visible. Among surgical procedures, subcision and microneedling are the most popular with good efficacy in atrophic acne scars except icepick scars. Punch techniques may be used for icepick scars. ${ }^{55}$ Ablative lasers, such as $\mathrm{CO}_{2}$ or erbium:yttrium aluminum garnet (Er: YAG), are effective in atrophic acne scars. Ablative fractional lasers have also been investigated and demonstrated an improved risk profile. Multiple treatments are necessary in case of deep scars. Nonablative lasers may be used in mild acne scarring as an alternative. Laser treatments are relatively expensive and have their own risks, such as postinflammatory hyperpigmentation - particularly in ethnic skin - and scarring. ${ }^{56}$

Deep peels with trichloroacetic acid alone or in combination with other peels or microneedling can improve atrophic scars. Repeated treatments may be necessary depending on the depth of the scars. A $100 \%$ trichloroacetic acid peel is capable to improve even icepick scars. ${ }^{57}$

Other techniques have been developed, but clinical data of controlled trials are missing.

\section{Conclusion and outlook}

Dermal fillers belong to the armamentarium to improve acne scars. Their capability to augment soft tissue is the most obvious advantage. Tolerability, durability of the augmentation, adverse effects, and risk profiles differ between the various dermal filler types. Permanent fillers may exert very long-lasting effects, but in case of unwanted adverse effects, the complete removal of the material may be necessary. Temporary fillers need repeated treatments increasing the costs. HAFs have been shown to improve skin quality over time. Semipermanent fillers seem to be a good alternative. For safety reasons, deep injections are recommended.

When should dermal fillers be considered? Dermal fillers may be appropriate in soft atrophic scars of the rolling or boxcar type. HAF can improve the quality of overlying skin. Dermal fillers can be used either alone or in combinations with other procedures such as subcision, microneedling, ablative or fractional lasers, and peels. Although the use of dermal fillers is widespread, not much controlled studies have been published on their use in acne scars. Most data are from case reports and uncontrolled studies. The outcome and longevity of the tissue augmentation depend not only on the filler type and injection technique but also on the scar type. Best results have been obtained for rolling scars and depressed boxcar scars. In contrast, icepick scars and hypertrophic scars or acne keloids will not benefit from dermal filler injections at all. In practice, a multimodal approach seems to fulfill patient's expectation at best. ${ }^{55,58}$

Fillers that can modulate ECM to reduce scarring seem to be the most interesting for future developments of a targeted treatment. Based on the experience with midfacial soft-tissue augmentation, targeted activation of white adipose tissue stem cells could be a prospective in filler use. ${ }^{59}$ Animal studies provide evidence that the combination of HA and stem cells leads to better and more stable results in tissue augmentation. ${ }^{60,61}$ This could be a step forward in tissue regeneration from which patients with acne scars may benefit in the future.

\section{Author contributions}

UW and AG conceived and designed the review, analyzed the data, wrote the first draft of the manuscript, agreed with the manuscript results and conclusions, jointly developed the structure and arguments for the article, and made critical revisions and approved final version. Both the authors reviewed and approved the final version of the manuscript for submission. All authors contributed toward data analysis, drafting and critically revising the paper and agree to be accountable for all aspects of the work.

\section{Ethics}

As a requirement of publication, authors have provided to the publisher signed confirmation of compliance with legal and ethical obligations including but not limited to the following: authorship and contributorship, conflicts of interest, privacy and confidentiality, and (where applicable) protection of human and animal research subjects. 
The authors have read and confirmed their agreement with the ICMJE authorship and conflict of interest criteria. The authors have also confirmed that this article is unique and not under consideration or published in any other publication, and that they have permission from rights holders to reproduce any copyrighted material.

\section{Disclosure}

The authors report no conflicts of interest in this work.

\section{References}

1. Dréno B. Recent data on epidemiology of acne. Ann Dermatol Venereol. 2010;137(Suppl 2):S49-S51.

2. Tan JK, Bhate K. A global perspective on the epidemiology of acne. Br J Dermatol. 2015;172(Suppl 1):3-12.

3. Park SY, Kwon HH, Min S, Yoon JY, Suh DH. Epidemiology and risk factors of childhood acne in Korea: a cross-sectional community based study. Clin Exp Dermatol. Epub 2015 May 25.

4. Holzmann R, Shakery K. Postadolescent acne in females. Skin Pharmacol Physiol. 2014;27(Suppl 1):3-8.

5. Zouboulis CC, Bettoli V. Management of severe acne. Br J Dermatol. 2015;172(Suppl 1):27-36.

6. Goodman GJ, Baron JA. Postacne scarring - a quantitative global scarring grading system. J Cosmet Dermatol. 2006;5:48-52.

7. Cachafeiro TH, Escobar GF, Maldonado G, Cestari TF. Translation into Brazilian Portuguese and validation of the "quantitative global scarring grading system for post-acne scarring”. An Bras Dermatol. 2014;89(5): 851-853.

8. Kim DI, Garrison RC, Thompson G. A near fatal case of pathological skin picking. Am J Case Rep. 2013;14:284-287.

9. Sato T, Kurihara H, Akimoto N, Noguchi N, Sasatsu M, Ito A. Augmentation of gene expression and production of promatrix metalloproteinase 2 by Propionibacterium acnes-derived factors in hamster sebocytes and dermal fibroblasts: a possible mechanism for acne scarring. Biol Pharm Bull. 2011;34(2):295-299.

10. Sato T, Shirane T, Noguchi N, Sasatsu M, Ito A. Novel anti-acne actions of nadifloxacin and clindamycin that inhibit the production of sebum, prostaglandin $\mathrm{E}(2)$ and promatrix metalloproteinase-2 in hamster sebocytes. J Dermatol. 2012;39(9):774-780.

11. Holland DB, Jeremy AHT, Roberts SG, Seukeran DC, Layton AM, Cunliffe WJ. Inflammation in acne scarring: a comparison of the responses in lesions from patients prone and not prone to scar. Br J Dermatol. 2004; 150(1):72-81.

12. Davis EC, Callender VD. A review of acne in ethnic skin: pathogenesis, clinical manifestations, and management strategies. J Clin Aesthet Dermatol. 2010;3(4):24-38.

13. Fabbrocini G, Annunziata MC, D'Arco V, et al. Acne scars: pathogenesis, classification and treatment. Dermatol Res Pract. 2010; 2010:893080.

14. Jansen T, Podda M. Therapy of acne scars. J Dtsch Dermatol Ges. 2010;8(Suppl 1):S81-S88.

15. Nast A, Dréno B, Bettoli V, et al. European dermatology forum. European evidence-based (S3) guidelines for the treatment of acne. J Eur Acad Dermatol Venereol. 2012;26(Suppl 1):1-29.

16. Ahn CS, Rao BK. The life cycles and biological end pathways of dermal fillers. J Cosmet Dermatol. 2014;13(3):212-223.

17. Mercer SE, Kleinerman R, Goldenberg G, Emanuel PO. Histopathologic identification of dermal filler agents. J Drugs Dermatol. 2010;9(9): 1072-1078.

18. Wollina U, Goldman A. Dermal fillers: facts and controversies. Clin Dermatol. 2013;31(6):731-736.
19. Zielke H, Wölber L, Wiest L, Rzany B. Risk profiles of different injectable fillers: results from the injectable filler safety study (IFS Study). Dermatol Surg. 2007;34(1):1-10.

20. Cohen JL. Understanding, avoiding, and managing dermal filler complications. Dermatol Surg. 2008;34(Suppl 1):S92-S99.

21. Alam M, Gladstone H, Kramer EM, et al; American Society for Dermatologic Surgery. ASDS guidelines of care: injectable fillers. Dermatol Surg. 2008;34(Suppl 1):S115-S148.

22. De Boulle K, Heydenrych I. Patient factors influencing dermal filler complications: prevention, assessment, and treatment. Clin Cosmet Investig Dermatol. 2015;8:205-214.

23. Barnett JG, Barnett CR. Treatment of acne scars with liquid silicone injections: 30-year perspective. Dermatol Surg. 2005;31(11 pt 2): 1542-1549.

24. Fulton J, Caperton C. The optimal filler: immediate and long-term results with emulsified silicone (1,000 centistokes) with cross-linked hyaluronic acid. J Drugs Dermatol. 2012;11(11):1336-1341.

25. FDA. Federal register. 1998;63(1):87-88. Available from: http://www. fda.gov/ohrms/dockets/98fr/010298a.txt. Accessed July 25, 2015.

26. Lee JH, Choi HJ. Rare complication of silicone fluid injection presenting as multiple calcification and skin defect in both legs: a case report. Int $J$ Low Extrem Wounds. 2015;14(1):95-97.

27. Centers for Disease Control and Prevention (CDC). Acute renal failure associated with cosmetic soft-tissue filler injections - North Carolina, 2007. MMWR Morb Mortal Wkly Rep. 2008;57(17):453-456.

28. Wollina U. Silicone injections. J Cutan Aesthet Surg. 2012;5(3):197.

29. Choi HJ. Pseudocyst of the neck after facial augmentation with liquid silicone injection. J Craniofac Surg. 2014;25(5):e474-e475.

30. Lemperle G, Ott H, Charrier U, Hecker J, Lemperle M. PMMA microspheres for intradermal implantation: Part I. Animal research. Ann Plast Surg. 1991;26(1):57-63.

31. Bagal A, Dahiya R, Tsai V, Adamson PA. Clinical experience with polymethylmethacrylate microspheres (Artecoll) for soft-tissue augmentation: a retrospective review. Arch Facial Plast Surg. 2007;9(4):275-280.

32. Carvalho Costa IM, Salaro CP, Costa MC. Polymethylmethacrylate facial implant: a successful personal experience in Brazil for more than 9 years. Dermatol Surg. 2009;35(8):1221-1227.

33. Epstein RE, Spencer JM. Correction of atrophic scars with artefill: an open-label pilot study. J Drugs Dermatol. 2010;9(9):1062-1064.

34. Karnik J, Baumann L, Bruce S, et al. A double-blind, randomized, multicenter, controlled trial of suspended polymethylmethacrylate microspheres for the correction of atrophic facial acne scars. J Am Acad Dermatol. 2014;71(1):77-83.

35. FDA. US Food and Drug Administration. 2014. Available from: http:// www.accessdata.fda.gov/cdrh_docs/pdf2/P020012S009b.pdf. Accessed June 27, 2015.

36. Yamauchi PS. Emerging permanent filler technologies: focus on Aquamid. Clin Cosmet Investig Dermatol. 2014;7:261-266.

37. von Buelow S, von Heimburg D, Pallua N. Efficacy and safety of polyacrylamide hydrogel for facial soft-tissue augmentation. Plast Reconstr Surg. 2005;116(4):1137-1146.

38. Kalantar-Hormozi A, Mozafari N, Rasti M. Adverse effects after use of polyacrylamide gel as a facial soft tissue filler. Aesthet Surg J. 2008;28(2):139-142.

39. Beer K. A single-center, open-label study on the use of injectable poly-L-lactic acid for the treatment of moderate to severe scarring from acne or varicella. Dermatol Surg. 2007;33(Suppl 2):S159-S167.

40. Sadove R. Injectable poly-L-lactic acid: a novel sculpting agent for the treatment of dermal fat atrophy after severe acne. Aesthetic Plast Surg. 2009;33(1):113-116.

41. Sapra S, Stewart JA, Mraud K, Schupp R. A Canadian study of the use of poly-L-lactic acid dermal implant for the treatment of hill and valley acne scarring. Dermatol Surg. 2015;41(5):587-594.

42. Jacovella PF. Use of calcium hydroxylapatite (Radiesse) for facial augmentation. Clin Interv Aging. 2008;3(1):161-174. 
43. Goldberg DJ, Amin S, Hussain M. Acne scar correction using calcium hydroxylapatite in a carrier-based gel. J Cosmet Laser Ther. 2006;8(3): 134-136.

44. Treacy P. Treatment of Acne Scars with Radiesse. London: Aesthetic Medicine; 2008.

45. Elson ML. Clinical assessment of Zyplast implant: a year of experience for soft tissue contour correction. JAm Acad Dermatol. 1988;18(4 pt 1): 707-713.

46. Varnavides CK, Forster RA, Cunliffe WJ. The role of bovine collagen in the treatment of acne scars. Br J Dermatol. 1987;116(2): 199-206.

47. Sage RJ, Lopiccolo MC, Liu A, Mahmoud BH, Tierney EP, Kouba DJ. Subcuticular incision versus naturally sourced porcine collagen filler for acne scars: a randomized split-face comparison. Dermatol Surg. 2011;37(4):426-431.

48. Smith KC. Repair of acne scars with Dermicol-P35. Aesthet Surg J. 2009;29(3 Suppl):S16-S18.

49. Wollina U, Goldman A. Hyaluronic acid dermal fillers: safety and efficacy for the treatment of wrinkles, aging skin, body sculpturing and medical conditions. Clin Med Rev Ther. 2011;3:107-121.

50. Turlier V, Delalleau A, Casas C, et al. Association between collagen production and mechanical stretching in dermal extracellular matrix: in vivo effect of cross-linked hyaluronic acid filler. A randomised, placebo-controlled study. J Dermatol Sci. 2013;69(3):187-194.

51. Hasson A, Romero WA. Treatment of facial atrophic scars with Esthélis, a hyaluronic acid filler with polydense cohesive matrix (CPM). J Drugs Dermatol. 2010;9(12):1507-1509.
52. Halachmi S, Ben Amitai D, Lapidoth M. Treatment of acne scars with hyaluronic acid: an improved approach. J Drugs Dermatol. 2013;12(7): e121-e123.

53. Patel T, Tevet O. Effective treatment of acne scars using pneumatic injection of hyaluronic acid. J Drugs Dermatol. 2015;14(1):74-76.

54. Rzany B, Becker-Wegerich P, Bachmann F, Erdmann R, Wollina U. Hyaluronidase in the correction of hyaluronic acid-based fillers: a review and a recommendation for use. J Cosmet Dermatol. 2009;8(4): 317-323.

55. Gozali MV, Zhou B. Effective treatments of atrophic acne scars. J Clin Aesthet Dermatol. 2015;8(5):33-40.

56. Sobanko JF, Alster TS. Management of acne scarring, part I: a comparative review of laser surgical approaches. Am J Clin Dermatol. 2012; 13(5):319-330.

57. Hession MT, Graber EM. Atrophic acne scarring: a review of treatment options. J Clin Aesthet Dermatol. 2015;8(1):50-58.

58. O'Daniel TG. Multimodal management of atrophic acne scarring in the aging face. Aesthetic Plast Surg. 2011;35(6):1143-1150.

59. Wollina U. Midfacial rejuvenation by hyaluronic acid fillers and subcutaneous adipose tissue - a new concept. Med Hypotheses. 2015; 84(4):327-330.

60. Nowacki M, Pietkun K, Pokrywczyńska M, et al. Filling effects, persistence, and safety of dermal fillers formulated with stem cells in an animal model. Aesthet Surg J. 2014;34(8):1261-1269.

61. Huang SH, Lin YN, Lee SS, et al. New adipose tissue formation by human adipose-derived stem cells with hyaluronic acid gel in immunodeficient mice. Int J Med Sci. 2015;12(2):154-162.
Clinical, Cosmetic and Investigational Dermatology

\section{Publish your work in this journal}

Clinical, Cosmetic and Investigational Dermatology is an international, peer-reviewed, open access, online journal that focuses on the latest clinical and experimental research in all aspects of skin disease and cosmetic interventions. All areas of dermatology will be covered; contributions will be welcomed from all clinicians and

\section{Dovepress}

basic science researchers globally. This journal is indexed on CAS. The manuscript management system is completely online and includes a very quick and fair peer-review system, which is all easy to use. Visit http://www.dovepress.com/testimonials.php to read real quotes from published authors. 